\title{
ChemComm
}

\section{Charge control of the inverse trans-influence $\dagger$}

Cite this: Chem. Commun., 2015, 51,16671

Received 27th August 2015,

Accepted 25th September 2015

DOI: $10.1039 / \mathrm{c} 5 \mathrm{cc} 07211 \mathrm{e}$

www.rsc.org/chemcomm

The synthesis and characterization of uranium(vı) mono(imido) complexes, by the oxidation of corresponding uranium(v) species, are presented. These experimental results, paired with DFT analyses, allow for the comparison of the electronic structure of uranium(vi) mono(oxo) and mono(imido) ligands within a conserved ligand framework and demonstrate that the magnitude of the ground state stabilization derived from the inverse trans-influence (ITI) is governed by the relative charge localization on the multiply bonded atom or group.

While terminal oxo $\left(\mathrm{O}^{2-}\right)$ and imido $\left(\mathrm{RN}^{2-}\right)$ ligands are formally isolobal and isoelectronic, ${ }^{1-3}$ these ligands differ in the relative energy of their fragment orbitals and in the charge localization at $\mathrm{O}$ or $\mathrm{N}$ in their respective metal complexes. ${ }^{4-8}$ These subtle differences are most pronounced in the comparison of the reactivity and electronic structure of oxo and imido complexes of the early actinides (Th and U). Andersen's uranium(Iv) oxo and imido complexes of $\left[\left(\eta^{5}-1,2,4-\left(\mathrm{Me}_{3} \mathrm{C}\right)_{3} \mathrm{C}_{5} \mathrm{H}_{2}\right)_{2} \mathrm{U}=\mathrm{X}\right](\mathrm{X}=\mathrm{O}$, $\mathrm{NMe}$ ) are principle examples of this divergence. ${ }^{5,9,10}$ In these mid-valent complexes, the uranium oxo bond is significantly stronger, but much more polarized than the uranium imido bond, and, as a result, the imido engages in $[2+2]$ reactions with unsaturated substrates. The oxo, in contrast, principally reacts as a nucleophile. Such dramatic differences in oxo and imido reactivity and electronic structure are less common among transition metal complexes within conserved ligand frameworks,

\footnotetext{
${ }^{a}$ Friedrich-Alexander-University of Erlangen-Nürnberg, Department of Chemistry and Pharmacy, Inorganic Chemistry, Egerlandstr. 1, 91058 Erlangen, Germany. E-mail: karsten.meyer@fau.de; Fax: +49(0)9131 8527 367;

Tel: +49 (0)91318527360

${ }^{b}$ School of Chemistry, University of Nottingham, University Park, Nottingham, NG7 2RD, UK

${ }^{c}$ School of Chemistry, The University of Manchester, Oxford Road, Manchester, M13 9PL, UK

$\dagger$ Electronic supplementary information (ESI) available: General considerations, synthetic and spectroscopic as well as crystallograohic and computational details for 2-t-Bu, 2-Ad, and crystallographic details for 3-Ad. CCDC 894627, 894628, and 747048. For ESI and crystallographic data in CIF or other electronic format see DOI: $10.1039 / \mathrm{c} 5 \mathrm{cc} 07211 \mathrm{e}$
}

and the variable steric profile afforded by the imido substituent is often employed as a directing group to control reactivity. ${ }^{11}$

Since the report of the first uranium imido complex by Gilje in $1984,{ }^{12}$ an extensive body of work on uranium-ligand multiple bonding has developed. ${ }^{13-16}$ A major objective of these studies has been to understand the unique bonding in uranyl (and the actinyls) - the most common structural feature of high valent uranium compounds. ${ }^{17}$ In uranyl complexes, the two terminal oxo ligands are trans to each other and the $\mathrm{U}-\mathrm{O}$ distances are typically both short at $\sim 1.8 \AA$. The inverse trans-influence (ITI) has been proposed as the basis for this geometric preference. ${ }^{18-24}$ In this model charge-induced mixing of the pseudocore $6 p$ orbitals with the valence $5 f$ orbitals leads to contraction and strengthening of the bond trans to the oxo ligand. ${ }^{25,26}$ Theoretical and experimental work have established a molecular orbital basis for the ITI, ${ }^{6,27-34}$ but the role that charge localization plays in developing a quadrupolar polarization of the uranium core electrons remains experimentally untested.

Uranium bis(imido) complexes, possessing uranyl-like geometry with two trans-imido ligands, $[\mathrm{RN}=\mathrm{U}=\mathrm{NR}]^{n+}$, have been reported by Hayton and Boncella and serve as an excellent synthetic perturbation of the ITI. ${ }^{35-38}$ Surprisingly, in contrast to dioxo uranium complexes, cis-bis(imido) complexes (and even tris(imido) complexes) ${ }^{39,40}$ such as $\left[\mathrm{Cp}^{*}{ }_{2} \mathrm{U}(\mathrm{NPh})_{2}\right]\left(\mathrm{Cp}^{*}=\mathrm{C}_{5} \mathrm{Me}_{5}\right)$ can be prepared. ${ }^{41,42}$ Attempts to isolate analogous cis-dioxo complexes supported by $\mathrm{Cp}^{*}\left(\mathrm{Cp}^{*}=\mathrm{C}_{5} \mathrm{Me}_{5}\right)$ lead only to elimination of $\mathrm{Cp}^{*}$ dimer and precipitation of $\mathrm{UO}_{2}$ - indicating that deformation of $\mathrm{O}-\mathrm{U}-\mathrm{O}$ angle in uranyl is substantially more energy intensive than in the corresponding trans-bis(imido) complexes. ${ }^{9}$

However, appropriate complexes to disentangle the difference in high-valent uranium oxo and imido bonding have yet to be prepared. Complexes in which the highest uranium oxidation states (v) and (vI) are stabilized by a mono(imido) (or mono(oxo)) moiety are still scarce. ${ }^{43-51}$ Recently, we demonstrated that the ITI was key feature in determining geometry of the two $C_{\mathrm{s}}$ tacn-supported uranium(vi) mono(oxo) complexes $\left[\left({ }^{\mathrm{R}} \mathrm{ArO}\right)_{3^{-}}\right.$ tacn $\left.) \mathrm{U}^{\mathrm{VI}}(\mathrm{O})\right] \mathrm{SbF}_{6}\left(\left({ }^{\mathrm{R}} \mathrm{ArO}\right)_{3} \operatorname{tacn}^{3-}=1,4,7\right.$-tris $(3-R$-5-tert-butyl-2hydroxybenzyl)-1,4,7-triazacyclononane, $\mathrm{R}=t$-Bu, adamantyl) 


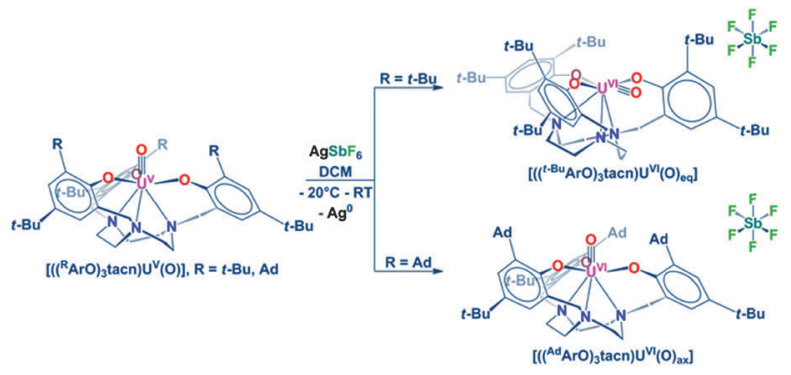

Scheme 1 Oxidation of $\left.\left[\left({ }^{\mathrm{R}} \mathrm{ArO}\right)_{3} \operatorname{tacn}\right) \mathrm{U}^{\mathrm{V}}(\mathrm{O})\right]$ with 1 equiv. $\mathrm{AgSbF}_{6}$ to give

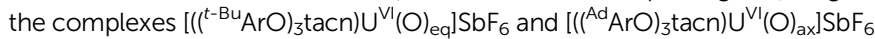
(eq. $=$ equatorial, ax. $=$ axial with respect to the tris(aryloxide) coordination). ${ }^{43}$

obtained via oxidation of the corresponding $C_{3}$ uranium(v) oxo compounds with silver(I) salts (Scheme 1). ${ }^{43}$ Herein we report the synthesis of uranium(vi) mono(imido) complexes supported by the conserved ligand framework $\left(\left({ }^{\mathrm{R}} \mathrm{ArO}\right)_{3} \operatorname{tacn}^{3-}=1,4,7\right.$-tris $(3-$ $R$-5-tert-butyl-2-hydroxybenzyl)-1,4,7-triazacyclononane, $\mathrm{R}=t$-Bu, adamantyl). These $C_{3}$ complexes retain an axially ligated metalligand multiple bond in contrast to their oxo analogues. Theoretical modelling of these complexes demonstrates that charge localization at the multiply-bonded ligand (either $\left(\mathrm{O}^{2-}\right)$ or $\left(\mathrm{TMSN}^{2-}\right)$ ) is an essential component of the ITI.

The uranium(v) trimethylsilylimido complexes $\left[\left({ }^{\mathrm{R}} \mathrm{ArO}\right)_{3^{-}}\right.$ tacn) $\left.\mathrm{U}^{\mathrm{V}}\left(\mathrm{NSiMe}_{3}\right)\right]^{52}(\mathbf{1}-\mathrm{R}$, with $\mathrm{R}=t$ - $\mathrm{Bu}, \mathrm{Ad})$ can be oxidized with $\mathrm{AgSbF}_{6}$ to yield the uranium(vi) imido complexes $\left[\left(\left({ }^{\mathrm{R}} \mathrm{ArO}\right)_{3^{-}}\right.\right.$ tacn) $\mathrm{U}^{\mathrm{VI}}\left(\mathrm{NSiMe}_{3}\right) \mathrm{SbF}_{6}$ (2-R, see Scheme 2). Addition of one equivalent of $\mathrm{AgSbF}_{6}$ to cold, dark-brown methylene chloride solutions of 1-R results in an immediate colour change to black. After filtration through celite and removal of the solvent in vacuo, the uranium(vi) compounds 2-t-Bu and 2-Ad are obtained in near quantitative yields. In contrast to the previously reported $C_{\mathrm{s}} \mathrm{U}(\mathrm{vI})$ mono(oxo) species, an exclusively axial coordination mode of the imido ligands is observed in both the tert-butyl as well as the sterically more encumbered adamantyl derivatized uranium(vI) imido complexes. The coordination modes were established by ${ }^{1} \mathrm{H}$ NMR spectroscopy, showing the $C_{3}$ symmetry to be present in solution (see ESI $\dagger$ ), and confirmed by X-ray diffraction on single crystals of both compounds.

The structures of the imido complexes 2-t-Bu (Fig. 1) and 2-Ad (see ESI $\dagger$ ) are very similar. Their $\mathrm{U}-\mathrm{N}_{\text {imido }}$ bond distances are short, measuring 1.911(9) and 1.917(9) $\AA$ in 2-t-Bu (two independent molecules) and 1.921(4) $\AA$ in 2-Ad, consistent with previously reported $\mathrm{U}(\mathrm{vI})-\mathrm{N}_{\text {imido }}$ distances. ${ }^{44,45}$ The N-Si bond lengths are 1.750(10) $\AA$ for the $t$-Bu (both independent molecules) and 1.745(4) $\AA$ for the adamantyl imido, and the U-N-Si angles for both complexes are essentially linear for both

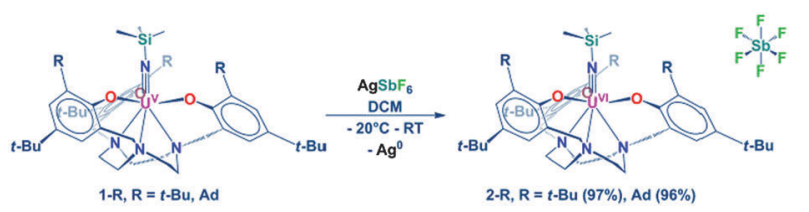

Scheme 2 Oxidation of $\left[\left(\left(^{\mathrm{R}} \mathrm{ArO}\right)_{3} \operatorname{tacn}\right) \cup^{\vee}\left(\mathrm{NSiMe}_{3}\right)\right]$ (1-R) with 1 equiv. $\mathrm{AgSbF}_{6}$ to form $\left.\left[\left({ }^{\mathrm{R}} \mathrm{ArO}\right)_{3} \mathrm{tacn}\right) \mathrm{U}^{\mathrm{VI}}\left(\mathrm{NSiMe}_{3}\right)\right] \mathrm{SbF}_{6}(\mathbf{2}-\mathrm{R})$.

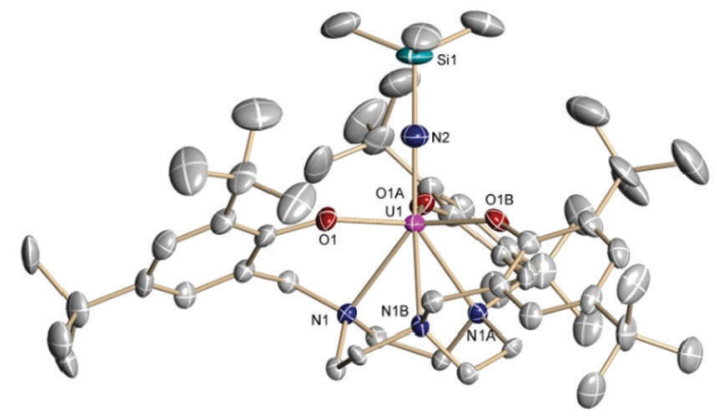

Fig. 1 Molecular structure of one of the two independent cations of $\left[\left(\left(^{t-B u} \mathrm{ArO}\right)_{3} \mathrm{tacn}\right) \mathrm{U}^{\mathrm{V} /}\left(\mathrm{NSiMe}_{3}\right)\right] \mathrm{SbF}_{6}$ in crystals of $\left[\left(\left(^{(-\mathrm{Bu}} \mathrm{ArO}\right)_{3} \mathrm{tacn}\right) \mathrm{U}^{\mathrm{Vl}}\left(\mathrm{NSiMe}_{3}\right)\right]-$ $\mathrm{SbF}_{6} \cdot 0.5\left[\mathrm{Na}(\mathrm{DME})_{3} \mathrm{SbF}_{6} \cdot 1.5 \mathrm{DME}(\mathbf{2}-\mathbf{t}-\mathrm{Bu})\right.$. Counter anion, co-crystallized solvent and $\mathrm{NaSbF}_{6}$, as well as hydrogen atoms are omitted for clarity. Thermal ellipsoids are at 50\% probability. Selected bond lengths ( $\AA$ ) and angles ( ${ }^{\circ}$ ): U-N $\mathrm{N}_{\text {imido: }}$ 1.911(9)/1.917(9); N-Si: 1.752(10)/1.750(10); U-O: 2.137(3)/2.134(4); U-N $\mathrm{N}_{\text {tacn }}: 2.617(4) / 2.619(4) ; U-N-S i: 180$.

complexes (2-t-Bu, $180.0^{\circ}$ and 2-Ad, $\left.175.8(3)^{\circ}\right)$. The slight deviation from linearity in 2-Ad is due to the increased steric clash with the ortho-adamantyl ligand substituents. The uranium center lies 0.195 and $0.189 \AA$ below the plane of the three aryloxide oxygen atoms for 2-t-Bu, while the out-of-plane shift of 2-Ad is smaller at $0.139 \AA$. This trend was found previously for isostructural complexes of the same chelating ligand system, e.g. $\left[\left(\left({ }^{\mathrm{R}} \mathrm{ArO}\right)_{3} \operatorname{tacn}\right) \mathrm{U}^{\mathrm{NV}}(\mathrm{OMe})\right]^{53}$ or $\left[\left(\left({ }^{\mathrm{R}} \mathrm{ArO}\right)_{3} \operatorname{tacn}\right) \mathrm{U}^{\mathrm{V}}(\mathrm{O})\right],{ }^{47}$ and is related to the greater steric demand of the adamantyl vs. tert-butyl groups in the ortho position of the aryloxide ligand pendant arms. The isoelectronic oxo ligand leads to a markedly different geometry at the uranium center in contrast to the axially bound imido ligands of the uranium(vi) complexes 2-R. In the compound with the sterically less encumbered $t$-Bu derivatized ligand, $\left[\left({ }^{-\mathrm{Bu}} \mathrm{ArO}\right)_{3}\right.$ tacn $\left.) \mathrm{U}^{\mathrm{VI}}(\mathrm{O})\right] \mathrm{SbF}_{6}$, the terminal oxo is coordinated within the equatorial plane, along with the three aryloxide arms of the chelating ligand and the $\mathrm{U}-\mathrm{O}_{\text {aryloxide }}$ bond trans to the oxo ligand is shortened. ${ }^{43}$

In order to understand these observed differences, and to compare the electronic structures of the $\mathrm{U}(\mathrm{vI})$ imido and $\mathrm{U}(\mathrm{vI})$ oxo complexes, restricted DFT calculations were carried out, employing a ZORA/TZP all-electron basis set on the axial and hypothetical equatorial isomers of $\mathbf{2 - t}$-Bu and 2-Ad. While the calculation of 2-Ad with an imido ligand hypothetically bound in the equatorial plane did not converge, suggesting instability of this geometrical isomer, calculations for both axial and equatorial imido coordination converged for $\mathbf{2}-\boldsymbol{t}$-Bu. However, for the axially bound imido ligand in $\mathbf{2 - t}-\mathbf{B u}_{\mathrm{ax}}$, the $\mathrm{U}-\mathrm{N}$ distance is calculated to be slightly shorter by $0.017 \AA$ compared to the equatorial derivative. The calculated energy of $\mathbf{2 - t}-\mathbf{B u}_{\mathbf{a x}}$ is approximately $11 \mathrm{kcal} \mathrm{mol}^{-1}$ lower in absolute energy than $\mathbf{2 - t}-\mathbf{B u}_{\text {eq }}$, which fully agrees with the experimentally observed axial coordination of the imido ligand. For the respective oxo complexes the equatorial coordination was calculated to be more stable than the axial by approximately $6 \mathrm{kcal} \mathrm{mol}^{-1}$. These data suggest that the ITI is weaker for the imido compound than for the oxo counterpart. Additionally, a simple consideration of the calculated Mulliken charge to oxidation number ratio for the experimentally observed isomers of $2-t-\mathbf{B u}_{\mathrm{ax}}(0.44$ for $2.61 / 6)$ and 
Table 1 Selected calculated bond lengths, Nalewajski-Mrozek bond indices, and Mulliken charges for $\left.\mathbf{2}-\mathbf{t}-\mathrm{Bu}_{\mathrm{ax}}, \mathbf{2}-\mathbf{t}-\mathrm{Bu}_{\mathrm{eq}}, \mathbf{2}-\mathbf{A d}_{\mathrm{ax}},\left[\left(\left(^{t-B u} \mathrm{ArO}\right)_{3} \mathrm{tacn}\right) \mathrm{U}^{\mathrm{V}}(\mathrm{O})\right)_{\mathrm{eq}}\right]^{+},{ }^{43}$ and $\left[\left(\left(^{t-B u} \mathrm{ArO}\right)_{3} \operatorname{tacn}\right) U^{\mathrm{V} 1}(\mathrm{O})_{a x}\right]^{+43}$

\begin{tabular}{|c|c|c|c|}
\hline Complex & $\begin{array}{l}\text { Calc. bond length } \\
\text { (and indice) }^{a}\end{array}$ & $\begin{array}{l}\text { Calc. Mulliken } \\
\text { charge on U }\end{array}$ & $\begin{array}{l}\text { Calc. Mulliken charge } \\
\text { on TMSN }_{\text {nitrene }} \text { or } \mathrm{O}_{\text {oxo }}\end{array}$ \\
\hline $2-t-\mathrm{Bu}_{\mathrm{ax}}$ & $1.9122(2.71)$ & +2.61 & -0.52 \\
\hline$\left[\left(\left(\left(^{t-\mathrm{Bu}} \mathrm{ArO}\right)_{3} \mathrm{tacn}\right) \mathrm{U}^{\mathrm{VI}}(\mathrm{O})_{\mathrm{eq}}\right]^{+43}\right.$ & $1.8273(2.67)$ & +2.52 & -0.63 \\
\hline$\left[\left(\left({ }^{t-\mathrm{Bu}} \mathrm{ArO}\right)_{3} \operatorname{tacn}\right) \mathrm{U}^{\mathrm{VI}}(\mathrm{O})_{\mathrm{ax}}\right]^{+43}$ & $1.8348(2.69)$ & +2.59 & -0.61 \\
\hline
\end{tabular}

$\left[\left(\left({ }^{t-\mathrm{Bu}} \mathrm{ArO}\right)_{3} \operatorname{tacn}\right) \mathrm{U}^{\mathrm{VI}}(\mathrm{O})_{\mathrm{eq}}\right]^{+43}(0.42$ for $2.52 / 6)$ indicates that the $\mathrm{U}-\mathrm{O}$ is slightly more covalent than the $\mathrm{U}-\mathrm{N}$ bond in $\mathbf{2 - t}-\mathbf{B} \mathbf{u}_{\mathbf{a x}}$. This result is in contrast to the mid-valent uranium oxo and imido complexes studied by Maron, Eisenstein, and Andersen, ${ }^{5,9,10}$ and suggests that the increased oxidation state and accompanied decrease in energy of the $5 f$ orbitals leads to better energy parity with $\mathrm{O} 2 \mathrm{p}$ orbitals than the $\mathrm{N} 2 \mathrm{p}$ orbitals.

While the steric demands of the trimethylsilylimido ligand are greater than for the oxo ligand, and thus steric influences should not be overlooked, DFT calculations clearly show that the $\mathrm{U} \equiv \mathrm{O}$ bond is more polarized than the $\mathrm{U} \equiv \mathrm{NR}$ bond and that the charge localized at $\mathrm{O}$ (in the oxo) is substantially greater than that localized at $\mathrm{N}$ (in the imides) (Table 1). Specifically, for the model complexes of the experimentally observed isomers 2- $t$ - $\mathbf{B u}_{\mathrm{ax}}$ and $\left[\left(\left({ }^{t-\mathrm{Bu}} \mathrm{ArO}\right)_{3} \operatorname{tacn}\right) \mathrm{U}^{\mathrm{VI}}(\mathrm{O})_{\mathrm{eq}}\right]^{+43}$ - the calculated charge on the $\mathrm{TMSN}^{2-}$ is substantially lower in magnitude than on the oxo $(-0.52$ versus -0.63$)$. In line with this observation, the calculated charge on the $\mathrm{TMSN}^{2-}$ in the hypothetical imide isomer, $2-t-\mathbf{B u}_{\text {eq }}$, is of insufficient magnitude $(-0.57)$ to induce a stabilizing ITI; and hence, is higher in energy than the axial isomer, $\mathbf{2 - t}-\mathbf{B} \mathbf{u}_{\mathbf{a x}}$. It should be noted that increased covalency with increased bond polarity are not conflicting trends. Covalency is driven both by valence orbital degeneracy and orbital overlap: the importance of both of these trends for determining the magnitude of covalent bonding is particularly pronounced in the f-elements. ${ }^{54}$

Since the molecular orbital description of the ITI primarily, ${ }^{25}$ but not exclusively, invokes involvement of a $6 \mathrm{p}$ orbital directed along the $\sigma$-bond axis we conclude that the oxo group induces the greater polarization of the metal atom core electrons. Mixing the $6 \mathrm{p}$ and the $5 \mathrm{f}$ orbitals induces a quadrupolar polarization because the orbitals are the same parity. This phenomenon leads to the observed shortening and strengthening of the bond to the trans disposed ligand. Consequently, the observed demand for a strong ligand coordinated trans to the terminal ligand $\left(\mathrm{O}^{2-} v s\right.$. $\left.\mathrm{TMSN}^{2-}\right)$ is more pronounced in the oxo species, $\left[\left(\left({ }^{t-\mathrm{Bu}} \mathrm{ArO}\right)_{3} \mathrm{tacn}\right) \mathrm{U}^{\mathrm{VI}}(\mathrm{O})_{\mathrm{eq}}\right] \mathrm{SbF}_{6}$.

In summary, we have synthesized terminal $\mathrm{U}(\mathrm{vI})$ imido complexes $\left.\left[\left({ }^{\mathrm{R}} \mathrm{ArO}\right)_{3} \mathrm{tacn}\right) \mathrm{U}^{\mathrm{VI}}\left(\mathrm{NSiMe}_{3}\right)\right] \mathrm{SbF}_{6}$ 2-R, with a conserved ligand framework, via oxidation of the $\mathrm{U}(\mathrm{v})$ compounds with $\mathrm{AgSbF}_{6}$. Unlike the $t$-Bu derivative of the $\mathrm{U}(\mathrm{vI})$ complex with equatorial oxo coordination, for which ITI was shown previously to be a key feature, we find a different behaviour for the terminal imido complex 2-t-Bu, with the imido group coordinating exclusively in the axial position. While DFT calculations suggest that coordination of the imido ligand in the equatorial position of the
2-t-Bu derivative (but not in 2-Ad) would be sterically possible, this structure is higher in absolute energy and therefore is a disfavoured ground state geometry. These results show that polarization of the metal-ligand bond (and the resultant quadrupolar polarization of the metal core electrons) is a key factor in determining the magnitude of the ITI in actinide complexes.

This research was supported by the German Bundesministerium für Bildung und Forschung (BMBF 2020+, 02NUK012C), the Deutsche Forschungsgemeinschaft (DFG) within SFB 583 and ME1754/2-1. The FAU Erlangen-Nürnberg is gratefully acknowledged for financial support, as is COST Action CM1006. S.T.L. thanks the Royal Society, EPSRC, ERC, and University of Nottingham for support. This work is dedicated to the 60th birthday of Prof. Manfred Scheer (University of Regensburg).

\section{Notes and references}

1 W. A. Nugent and J. A. Mayer, Metal-Ligand Multiple Bonds, Wiley, New York, 1988.

2 D. E. Wigley, Prog. Inorg. Chem., 1994, 42, 239.

3 H. S. La Pierre, S. G. Minasian, M. Abubekerov, S. A. Kozimor, D. K. Shuh, T. Tyliszczak, J. Arnold, R. G. Bergman and F. D. Toste, Inorg. Chem., 2013, 52, 11650.

4 W. A. Nugent, R. J. Mckinney, R. V. Kasowski and F. A. Vancatledge, Inorg. Chim. Acta, 1982, 65, L91.

5 N. Barros, D. Maynau, L. Maron, O. Eisenstein, G. F. Zi and R. A. Andersen, Organometallics, 2007, 26, 5059.

6 L. P. Spencer, P. Yang, S. G. Minasian, R. E. Jilek, E. R. Batista, K. S. Boland, J. M. Boncella, S. D. Conradson, D. L. Clark, T. W. Hayton, S. A. Kozimor, R. L. Martin, M. M. MacInnes, A. C. Olson, B. L. Scott, D. K. Shuh and M. P. Wilkerson, J. Am. Chem. Soc., 2013, 135, 2279.

7 T. L. Gianetti, H. S. La Pierre and J. Arnold, Eur. J. Inorg. Chem., 2013, 3771.

8 H. S. La Pierre, J. Arnold, R. G. Bergman and F. D. Toste, Inorg. Chem., 2012, 51, 13334.

9 G. F. Zi, L. Jia, E. L. Werkema, M. D. Walter, J. P. Gottfriedsen and R. A. Andersen, Organometallics, 2005, 24, 4251.

10 G. F. Zi, L. L. Blosch, L. Jia and R. A. Andersen, Organometallics, 2005, 24, 4602 .

11 S. J. Meek, R. V. O'Brien, J. Llaveria, R. R. Schrock and A. H. Hoyveda, Nature, 2011, 471, 461.

12 R. E. Cramer, K. Panchanatheswaran and J. W. Gilje, J. Am. Chem. Soc., 1984, 106, 1853.

13 T. W. Hayton, Chem. Commun., 2013, 49, 2888.

14 T. W. Hayton, Dalton Trans., 2010, 39, 1145.

15 S. T. Liddle, Angew. Chem., Int. Ed., 2015, 54, 8604.

16 H. S. La Pierre and K. Meyer, Prog. Inorg. Chem., 2014, 58, 303.

17 Z. Y. Zhang and R. M. Pitzer, J. Phys. Chem. A, 1999, 103, 6880.

18 R. G. Denning, in Electronic Structure and Bonding in Actinyl Ions, in Structure and Bonding, ed. D. M. P. Mingos, Springer-Verlag, Berlin, 1992, p. 215.

19 K. Tatsumi and R. Hoffmann, Inorg. Chem., 1980, 19, 2656.

20 W. R. Wadt, J. Am. Chem. Soc., 1981, 103, 6053.

21 P. Pyykkö, L. J. Laakkönen and K. Tatsumi, Inorg. Chem., 1989, 28, 1801. 
22 N. Kaltsoyannis, Inorg. Chem., 2000, 39, 6009.

23 R. G. Denning, J. C. Green, T. E. Hutchings, C. Dallera, A. Tagliaferri, K. Giarda, N. B. Brookes and L. Braicovich, J. Chem. Phys., 2002, 117, 8008 .

24 S. Matsika and R. M. Pitzer, J. Phys. Chem. A, 2001, 105, 637.

25 E. O'Grady and N. Kaltsoyannis, J. Chem. Soc., Dalton Trans., 2002, 1233. 26 H. S. La Pierre and K. Meyer, Inorg. Chem., 2013, 52, 529.

27 D. M. King, F. Tuna, E. J. L. McInnes, J. McMaster, W. Lewis, A. J. Blake and S. T. Liddle, Science, 2012, 337, 717.

28 T. Vitova, J. C. Green, R. G. Denning, M. Loeble, K. Kvashnina, J. J. Kas, K. Jorissen, J. J. Rehr, T. Malcherek and M. A. Denecke, Inorg. Chem., 2015, 54, 174.

29 S. G. Minasian, J. L. Krinsky and J. Arnold, Chem. - Eur. J., 2011, 17, 12234.

30 A. J. Lewis, P. J. Carroll and E. J. Schelter, J. Am. Chem. Soc., 2013, 135, 13185.

31 A. J. Lewis, K. C. Mullane, E. Nakamaru-Ogiso, P. J. Carroll and E. J. Schelter, Inorg. Chem., 2014, 53, 6944.

32 D. M. King, F. Tuna, J. McMaster, W. Lewis, A. J. Blake, E. J. L. McInnes and S. T. Liddle, Angew. Chem., Int. Ed., 2013, 52, 4921.

33 D. M. King, F. Tuna, E. J. L. McInnes, J. McMaster, W. Lewis, A. J. Blake and S. T. Liddle, Nat. Chem., 2013, 5, 482.

34 D. M. King, J. McMaster, F. Tuna, E. J. L. McInnes, W. Lewis, A. J. Blake and S. T. Liddle, J. Am. Chem. Soc., 2014, 136, 5619.

35 T. W. Hayton, J. M. Boncella, B. L. Scott, P. D. Palmer, E. R. Batista and P. J. Hay, Science, 2005, 310, 1941.

36 T. W. Hayton, J. M. Boncella, B. L. Scott and E. R. Batista, J. Am. Chem. Soc., 2006, 128, 12622.

37 T. W. Hayton, J. M. Boncella, B. L. Scott, E. R. Batista and P. J. Hay, J. Am. Chem. Soc., 2006, 128, 10549.

38 R. E. Jilek, L. P. Spencer, R. A. Lewis, B. L. Scott, T. W. Hayton and J. M. Boncella, J. Am. Chem. Soc., 2012, 134, 9876.

39 N. H. Anderson, S. O. Odoh, Y. Yao, U. J. Williams, B. A. Schaefer, J. J. Kiernicki, A. J. Lewis, M. D. Goshert, P. E. Fanwick, E. J. Schelter, J. R. Walensky, L. Gagliardi and S. C. Bart, Nat. Chem., 2014, 6, 919.
40 N. H. Anderson, H. Yin, J. J. Kiernicki, P. E. Fanwick, E. J. Schelter and S. C. Bart, Angew. Chem., Int. Ed., 2015, 54, 9386.

41 D. S. J. Arney, C. J. Burns and D. C. Smith, J. Am. Chem. Soc., 1992, 114, 10068.

42 J. L. Kiplinger, D. E. Morris, B. L. Scott and C. J. Burns, Chem. Commun., 2002, 30.

43 B. Kosog, H. S. La Pierre, F. W. Heinemann, S. T. Liddle and K. Meyer, J. Am. Chem. Soc., 2012, 134, 5284.

44 D. S. J. Arney and C. J. Burns, J. Am. Chem. Soc., 1993, 115, 9840.

45 D. S. J. Arney and C. J. Burns, J. Am. Chem. Soc., 1995, 117, 9448.

46 J. F. de Wet and J. G. H. du Preez, J. Chem. Soc., Dalton Trans., 1978, 592.

47 S. C. Bart, C. Anthon, F. W. Heinemann, E. Bill, N. M. Edelstein and K. Meyer, J. Am. Chem. Soc., 2008, 130, 12536.

48 S. Fortier, N. Kaltsoyannis, G. Wu and T. W. Hayton, J. Am. Chem. Soc., 2011, 133, 14224.

49 D. P. Mills, O. J. Cooper, F. Tuna, E. J. L. McInnes, E. S. Davies, J. McMaster, F. Moro, W. Lewis, A. J. Blake and S. T. Liddle, J. Am. Chem. Soc., 2012, 134, 10047.

50 C. R. Graves, B. L. Scott, D. E. Morris and J. L. Kiplinger, J. Am. Chem. Soc., 2007, 129, 11914.

51 C. R. Graves, P. Yang, S. A. Kozimor, A. E. Vaughn, D. L. Clark, S. D. Conradson, E. J. Schelter, B. L. Scott, J. D. Thompson, P. J. Hay, D. E. Morris and J. L. Kiplinger, J. Am. Chem. Soc., 2008, 130, 5272 .

52 I. Castro-Rodriguez, K. Olsen, P. Gantzel and K. Meyer, J. Am. Chem. Soc., 2003, 125, 4565.

53 B. Kosog, H. S. La Pierre, M. A. Denecke, F. W. Heinemann and K. Meyer, Inorg. Chem., 2012, 51, 7940.

54 M. W. Löble, J. M. Keith, A. B. Altman, S. C. E. Steiber, E. R. Batista, K. S. Boland, S. D. Conradson, D. L. Clark, J. Lezama Pacheco, S. A. Kozimor, R. L. Martin, S. G. Minasian, A. C. Olson, B. L. Scott, D. K. Shuh, T. Tyliszczak, M. P. Wilkerson and R. A. Zehnder, J. Am. Chem. Soc., 2015, 137, 2506. 